\title{
Plasma levels of soluble ACE2are associated with sex, Metabolic Syndrome, and its biomarkers in a large cohort, pointing to a possible mechanism for increased severity in COVID-19
}

\author{
Sergey A. Kornilov* (D), Isabelle Lucas, Kathleen Jade, Chengzhen L. Dai, Jennifer C. Lovejoy and Andrew T. Magis
}

Keywords: ACE2, SARS-CoV-2, COVID-19, Metabolic syndrome, GGT, Liver function

To the Editor:

Patients at high risk for mortality from COVID-19, the disease caused by severe acute respiratory syndrome coronavirus 2 (SARS-CoV-2), are more likely to be older and male and have chronic diseases such as hypertension, diabetes, cardiovascular, and chronic lung disease $[1,2]$. Although the mechanisms behind these associations are poorly understood, this increased risk could be partly associated with increased expression of the cellular receptor of SARS-CoV-2, angiotensin-converting enzyme-2, found at elevated levels in older individuals, men, and in cardiovascular and inflammatory conditions $[3,4]$. It maintains homeostasis of the renin-angiotensin system and converts angiotensin II to angiotensin 1-7, which has vasodilatory and anti-inflammatory properties. The membrane-bound form (mACE2) is highly expressed in the heart, airways, kidney, and liver tissue, and the enzymatically active soluble form (sACE2) is generated in response to inflammatory signals and disease via $\mathrm{mACE} 2$ shedding.

We interrogated the associations between plasma concentrations of sACE2 and biomarkers of metabolic syndrome (body mass index, BMI; blood pressure; glycemic

\footnotetext{
* Correspondence: sergey.kornilov@isbscience.org Institute for Systems Biology, Seattle, WA 401 Terry Ave N, Seattle, WA 98109-5263, USA
}

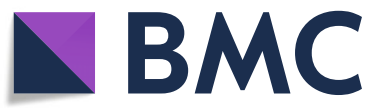

( The Author(s). 2020 Open Access This article is licensed under a Creative Commons Attribution 4.0 International License, which permits use, sharing, adaptation, distribution and reproduction in any medium or format, as long as you give appropriate credit to the original author(s) and the source, provide a link to the Creative Commons licence, and indicate if changes were made. The images or other third party material in this article are included in the article's Creative Commons licence, unless indicated otherwise in a credit line to the material. If material is not included in the article's Creative Commons licence and your intended use is not permitted by statutory regulation or exceeds the permitted use, you will need to obtain permission directly from the copyright holder. To view a copy of this licence, visit http://creativecommons.org/licenses/by/4.0/. The Creative Commons Public Domain Dedication waiver (http://creativecommons.org/publicdomain/zero/1.0/) applies to the data made available in this article, unless otherwise stated in a credit line to the data. markers; and lipid levels), adiposity (plasma leptin and serum adiponectin), inflammation (high-sensitivity Creactive protein, hsCRP, white blood cell count, and interleukin-8), and liver damage (alanine aminotransferase, aspartate transaminase, and gamma-glutamyltransferase, GGT) in a large cohort of participants in a commercial wellness program who had undergone comprehensive multi-omic profiling $(N=2051 ; 1238$ women and 813 men, aged 22 to 87 years, $M=47.3, \mathrm{SD}=11.71$ ) (see [5] for details). Clinical laboratory tests were performed in CLIA-certified laboratories by Quest Diagnostics or LabCorp. Plasma sACE2 and leptin levels were measured via proximity extension immunoassaying using Olink ${ }^{\circ}$ Cardiovascular II proteomics panel. Analyses were performed using transformed and scaled biomarker values in a robust linear regression framework controlling for age, sex (where appropriate), 8 genetic principal components, smoking, vendor, season, use of diabetes, cholesterol-lowering, and ACE-inhibitor medications.

Confirming results from recent studies [3, 4], we found higher plasma sACE2 levels in men compared to women $\left(P=2 \times 10^{-16}\right)$, and in older individuals $\left(P=8.6 \times 10^{-11}\right)$, with the age association more pronounced in women (for the interaction, $P_{\text {int }}=0.02$ ). We found higher levels of sACE2 in post-menopausal women, compared to premenopausal women $(P=0.02$; see Fig. 1$)$. 

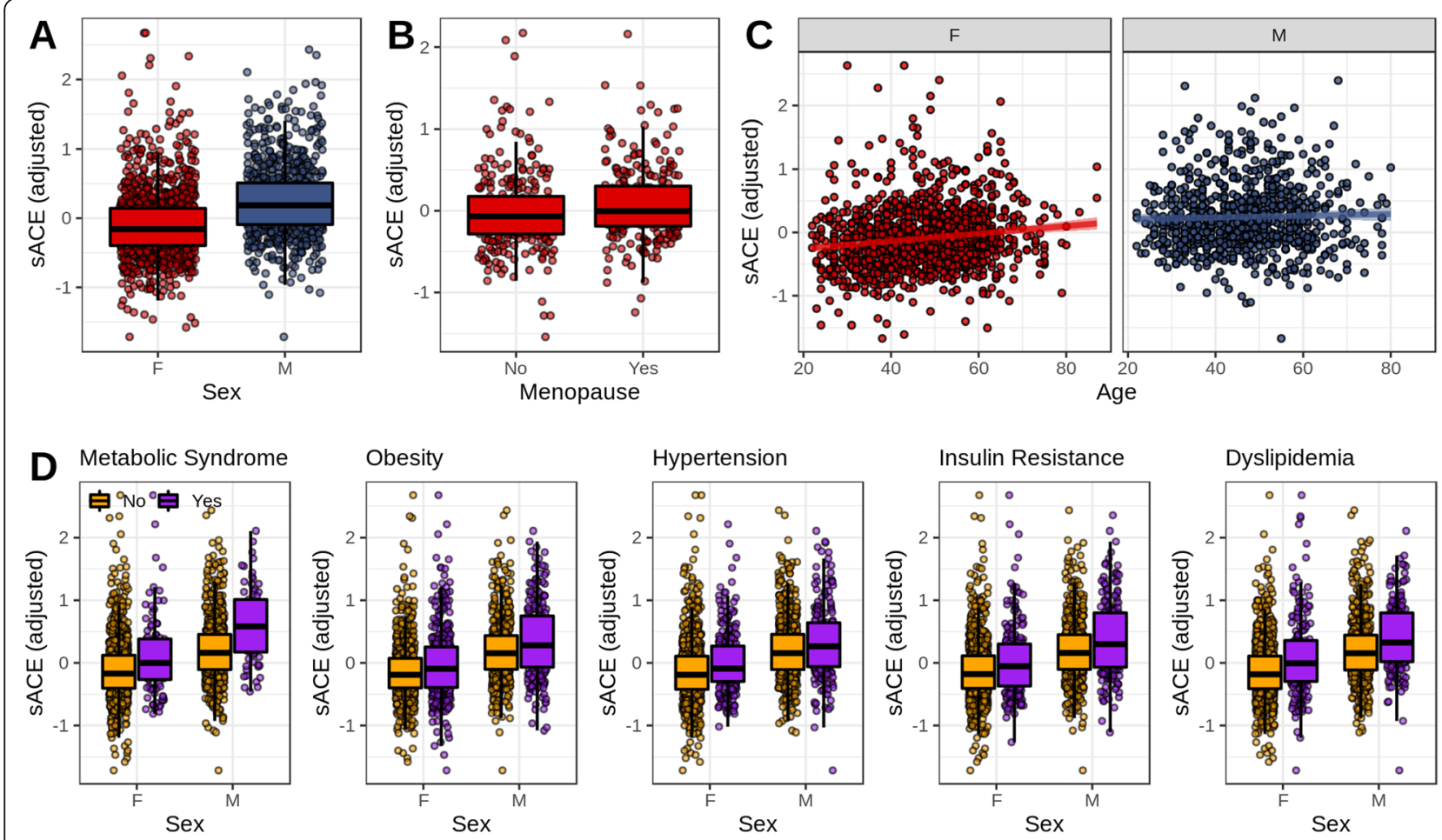

Fig. 1 The associations of plasma SACE2 levels with sex, age, and metabolic syndrome (MetS). a Sex differences in plasma sACE2 levels. b Differences in SACE2 levels between pre- $(N=272)$ and post-menopausal $(N=251)$ women over 35 years of age. c Associations between sACE2 and age. $\mathbf{d}$ Differences in SACE2 levels in individuals who do vs. who do not meet diagnostic criteria for MetS and its subcomponents. The following diagnostic criteria, based on WHO guidelines, were used: obesity, BMI $>30 \mathrm{~kg} / \mathrm{m}^{2}$; hyperglycemia, fasting glucose $>100 \mathrm{mg} / \mathrm{dl}$ or other evidence of insulin resistance (e.g., prescription); hypertension, systolic/diastolic blood pressure $\geq 140 / 90 \mathrm{~mm} / \mathrm{hg}$; dyslipidemia, triglycerides $>150$ or HDL-C $<35$ for men and $<39$ for women. Overall status was determined as MetS if the individual met criteria for insulin resistance and satisfied at least one other domain criterion for the syndrome. SACE2, soluble ACE2 (normalized protein expression, NPX, values adjusted for covariates and scaled)
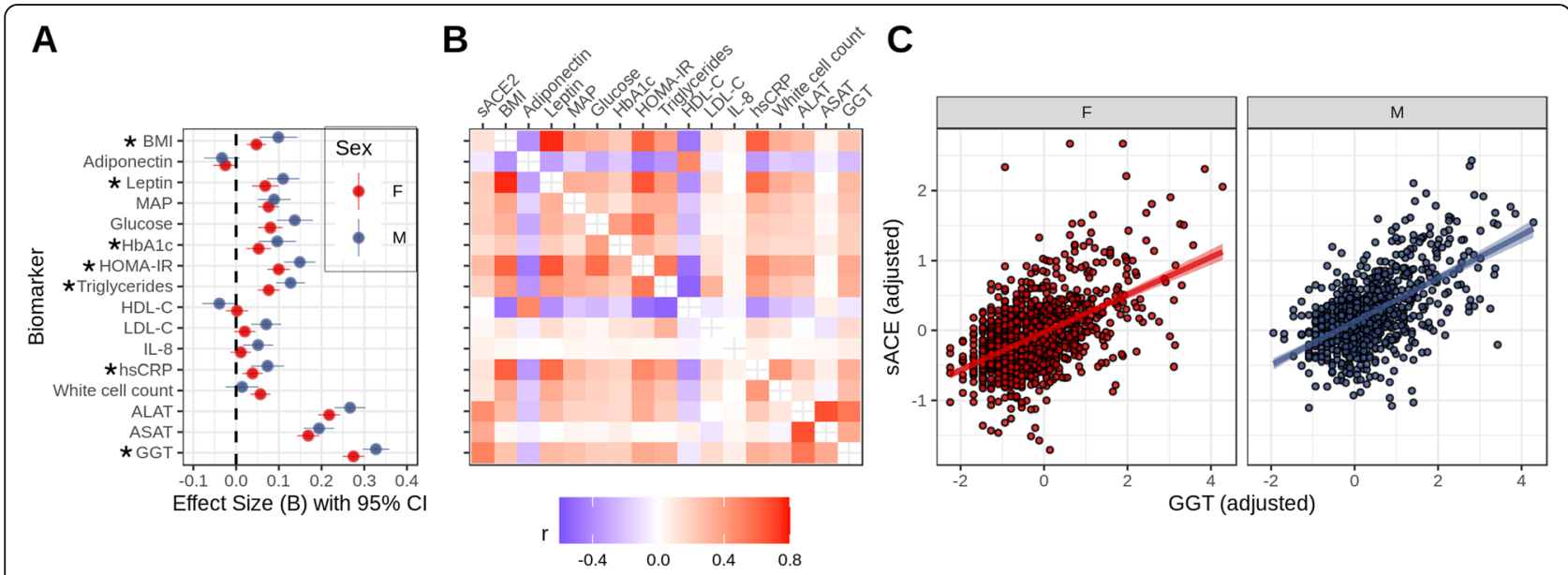

Fig. 2 Associations between SACE2 and biomarkers of metabolic syndrome, inflammation, and liver damage. a Marginal Effect size (B) estimates from robust linear regressions predicting SACE2 from biomarkers estimated for men and women separately. Biomarkers for which a significant interaction with sex was established are marked with an asterisk. b Partial Spearman correlations between study biomarkers and sACE2 levels. c Scatterplot of associations between GGT and SACE2. BMI, body mass index; MAP, mean arterial blood pressure; HbA1c, glycohemoglobin A1c; HOMA-IR, homeostatic model assessment of insulin resistance; HDL-C, high-density lipoprotein cholesterol; LDL-C, low-density lipoprotein cholesterol; IL-8, interleukin 8; hsCRP, high-sensitivity C-reactive protein; ALAT, alanine aminotransferase; ASAT, aspartate transaminase;

GGT, gamma-glutamyl-transferase 
Individuals who met World Health Organization's diagnostic criteria for metabolic syndrome (MetS) $(N=$ 171) displayed elevated plasma sACE2 levels compared to controls $\left(N=1880 ; P=4.7 \times 10^{-5}\right)$; the effect was stronger in men $\left(P_{\text {int }}=8.9 \times 10^{-5}\right)$. All of MetS component biomarkers were positively associated with plasma sACE2 (see Fig. 2). The associations were significantly stronger in men for biomarkers of obesity and adiposity (BMI, $P_{\text {int }}=0.0123$; leptin, $P_{\text {int }}=0.0342$ ) and insulin resistance and hyperglycemia (HbA1c, $P_{\text {int }}=0.0368$; HOMA-IR, $\left.P_{\text {int }}=0.042\right)$, as well as triglycerides $\left(P_{\text {int }}=\right.$ $0.0134)$ and serum hsCRP $\left(P_{\text {int }}=0.041\right)$. The strongest association was observed between sACE2 and GGT $(P=$ $\left.3.44 \times 10^{-90}\right)$, an important indicator of oxidative stress, liver, and bile duct damage. This association was also stronger in men (Pint $=0.01)$.

The robust pattern of associations between increased plasma sACE and MetS points to the possible shared pathways in cardiometabolic disease and COVID-19, implicating insulin resistance, chronic inflammation, and liver damage. This is intriguing given that both sACE2 and $\mathrm{mACE} 2$ have been shown to be upregulated in a rat model of chronic liver disease [6] and that sACE2 levels are higher in patients with heart failure [4]. The upregulation may be related to the tissue-specific patterns of increased SARS-CoV-2 infectivity in patients with cardiometabolic disease and/or liver damage and warrants further research on SACE2 as a potential biomarker for COVID-19 severity.

\section{Abbreviations}

sACE2/mACE2: Soluble/membrane-bound angiotensin-converting enzyme-2; MetS: Metabolic syndrome; GGT: Gamma-glutamyl-transferase; BMI: Body mass index; HbA1c: Glycohemoglobin A1c; HOMA-IR: Homeostatic model assessment of insulin resistance; hsCRP: High-sensitivity C-reactive protein

\section{Acknowledgements}

The authors express their gratitude to the members of the Arivale program for granting the permission to use their deidentified data for research and to Mr. Brett Smith at the Institute for Systems Biology for his contribution to the study.

\section{Authors' contributions}

SK, ILB, KJ, JL, CD, and AM conceptualized the study and drafted the manuscript. SK, CD, and AM performed data quality control and assurance, transformation, and data analysis. All authors critically revised the manuscript. The authors read and approved the final manuscript.

\section{Funding}

No external funding was received to complete this study.

\section{Availability of data and materials}

The dataset supporting the conclusions of this article is available from the authors upon request.

\section{Ethics approval and consent to participate}

All research was conducted in accordance to regulations and guidelines for observational research in human subjects. The study was reviewed and approved by the Western IRB (study number 1178906). The research was performed entirely using deidentified and aggregated data of individuals who had signed a research authorization allowing the use of their anonymized data in research. Per current US regulations for use of deidentified data, informed consent was not required.

\section{Consent for publication}

Not applicable.

\section{Competing interests}

The authors were previously employed by Arivale, Inc. and held stock options in the company. Arivale is now closed.

Received: 15 June 2020 Accepted: 1 July 2020

Published online: 22 July 2020

\section{References}

1. Tian W, Jiang W, Yao J, et al. Predictors of mortality in hospitalized COVID19 patients: a systematic review and meta-analysis. J Med Virol. 2020. https://doi.org/10.1002/jmv.26050.

2. Guo W, LM, Dong Y, et al. Diabetes is a risk factor for the progression and prognosis of COVID-19. Diab Metab Res Rev. 2020:e3319.

3. Swärd P, Edsfeldt A, Reepalu A, Jehpsson L, Rosengren BE, Karlsson MK. Age and sex differences in soluble ACE2 may give insights for COVID-19. Crit Care. 2020:24(1):221.

4. Sama IE, Ravera A, Santema BT, et al. Circulating plasma concentrations of angiotensin-converting enzyme 2 in men and women with heart failure and effects of renin-angiotensin-aldosterone inhibitors. Eur Heart J. 2020; 41(19):1810-7.

5. Zubair N, Conomos M, Hood L, et al. Genetic predisposition impacts clinical changes in a lifestyle coaching program. Sci Rep. 2019;9:6805.

6. Herath CB, Warner FJ, et al. Upregulation of hepatic Upregulation of hepatic angiotensin-converting enzyme 2 (ACE2) and angiotensin-(1-7) levels in experimental biliary fibrosis. J Hepatol. 2007;47(3):387-95.

\section{Publisher's Note}

Springer Nature remains neutral with regard to jurisdictional claims in published maps and institutional affiliations.

Ready to submit your research? Choose BMC and benefit from:

- fast, convenient online submission

- thorough peer review by experienced researchers in your field

- rapid publication on acceptance

- support for research data, including large and complex data types

- gold Open Access which fosters wider collaboration and increased citations

- maximum visibility for your research: over $100 \mathrm{M}$ website views per year

At $\mathrm{BMC}$, research is always in progress.

Learn more biomedcentral.com/submission 